\title{
Application of Secondary Ion Mass Spectrometry (SIMS)to Localize Chromium in Roots of Water Hyacinths Eichhornia crassipes (Mart.) Solms. in the Cachoeira Basin - Brazil.
}

\author{
P. A O Mangabeira ${ }^{*}$, A.A F.de Almeida ${ }^{*}$, , L. Labejof, A. H.Oliveira ${ }^{*}$, P. Galle ${ }^{\cdots}$, F. \\ Escaig "', M. I. G. Severo", D. C. Silva", M. S. Mielke', E. R. Lucena', M. C. Martins', K. \\ B. Santana ${ }^{*}$ M.S. Freitas*.
}

* Department of Biology - Universidade Estadual de Santa Cruz - UESC, Rodovia llhéus Itabuna, Km 16, CEP 45650000, Brazil. Email: paom@uesc.br

** Department of Nuclear Engineering - Universidade Federal de Minas Gerais - UFMG, Av. do Contorno 842, CEP 30110060 , Belo Horizonte, Brazil.

*** Service de Physique - Chimie - Ecole Nationale Vétérinaire d'Alfort. Alfort - France

\begin{abstract}
In the last years metal pollution has become one of the most important environmental problems. Concerning the high toxicity of these elements, both sensitive analytical measurements and methods for the control of the ecosystem are required to reveal and localize metals on organism. Due to high transportations rates and exchange phenomena of sediment bound metals and changes of imission concentrations, the estimation of pollution in aquatic systems like the river Cachoeira is problematic. Water and sediments samples can only refect momentary concentrations. In this context the use of biomonitoring methods offers the possibility to assess the heavy metals pollution. Secondary Ion Mass Spectrometry (SIMS) and Inductively coupled plasma mass spectrometry (ICP-MS) were used to localize chromium in Eichhornia crassipes. The pollution in chromium is bound to the clandestin tanf ery activity on the basin of the Cachoeira region south of Bahia (Brazil). Keywords: SIMS, Chromium, ICP-MS.

Water and sediment samples were collected along the cachoeira basin - Bahia - Brazil, from the region close to the source up to a distance of $120 \mathrm{Km}$. In the Cachoeira basin. The ion microscope SMI 300 CAMECA was used to obtain direct analytical images.

The multi-elementary methods ICP-MS and SIMS investigations has permitted a precise investigation of the concentrations of $\mathrm{Cr}$ in Eichhornia tissue. The high sensitivity of SIMS permitted the $\mathrm{Cr}$ detection in a larger number of root cells, principally in cell walls. The SIMS images provide a map of the distribution of $\mathrm{Na}^{+} \cdot \mathrm{Ca}^{+}$and $\mathrm{Cr}^{+}$in roots tissues (figure 1). The results have evidenced the sites of $\mathrm{Cr}$ in root, the cell wall, nucleus, and xylem vessel are the site of $\mathrm{Cr}$ accumulation in roots. The presence of chromium in nucleus is due to the strong binding of $\mathrm{Cr}^{3+}$ to DNA contributes to the reduction of $\mathrm{Cr}^{3+}$ solubility, stabilization of the double-strand structure of DNA [5]. The ICP-MS data confirm $E$. crassipes like bioindicator plant. The references materials used were Riverine Water, SLRS-3 (National Research Council of Canadá) and soils-7 (International Atomic Energy, Vienna, Austria). The results obtained by ICP-MS shows anormal values of $\mathrm{Cr}$ concentrations in water samples $(0,38 \mu \mathrm{g} / \mathrm{l})$, in soil samples $(63 \mu \mathrm{g} / \mathrm{g})$ and $70 \mu \mathrm{g} / \mathrm{g}$ in plant. $\mathrm{Cr}$ was mainly accumulated in roots. $E$. crassipes seems to have the ability to accumulation high concentration of $\mathrm{Cr}$ in its roots. Although the high amount of $\mathrm{Cr}$ in the roots might be partly due to physical adsorption on the cell walls, it can be deduced that more than $25 \%$ of the total $\mathrm{Cr}$ concentration was associated with the protoplasmic fraction. Cross and
\end{abstract}


longitudinal sections of $E$. crassipes roots shows the existence of deposits in symplastic and apoplastic areas. Chemical analysis using ICP-MS, confirms SIMS analysis on the presence of $\mathrm{Cr}$ in roots cell walls. The use of ICP-MS, to investigate the same organs as the ones investigated by SIMS, provided complementary results on chromium study.
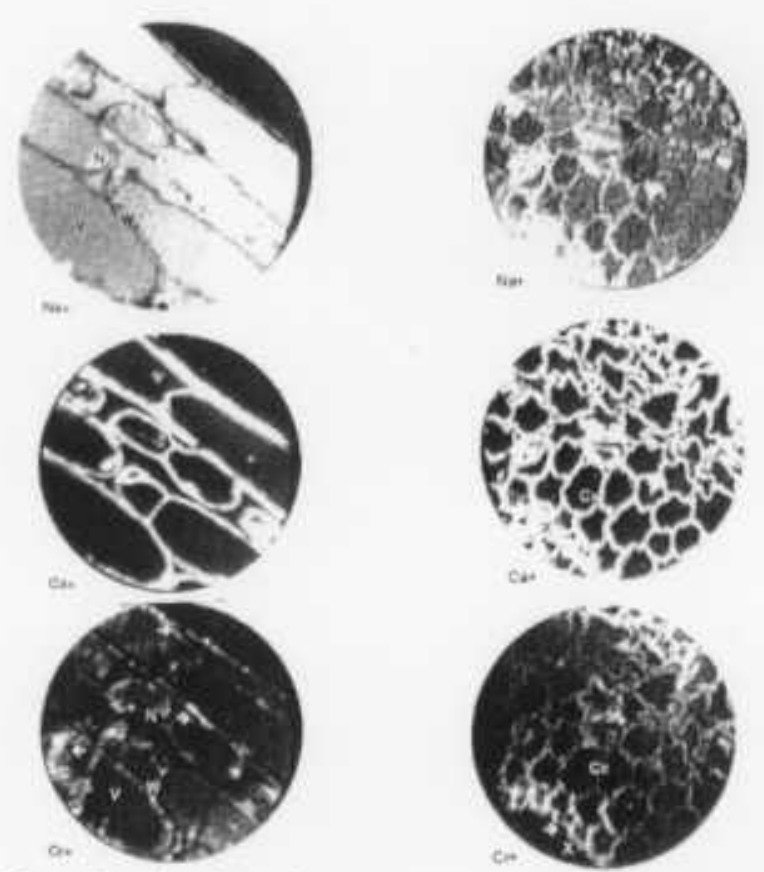

Fig 1. SIMS image of longitudinal and transverse section of Eichhornia crassipes roots, showing the cortex area $(\mathrm{Cx})$, cell wall $(\mathrm{w})$, nucleus $(\mathrm{N})$, vacuole $(\mathrm{V})$ and Xylem $(X)$. The images shows ab indance of chromium in root cell walls. Calcium image (ca), Sodium image $(\mathrm{Na})$ and Chromium image $(\mathrm{Cr})$.

\section{References}

[1] Mangabeira, P., Mushrifah, I. , Laffray, D. , Severo, M. I. G., Oliveira, A. H. , Escaig, F., and Galle, P. , Accumulation and Distribution of Chromium in the Tomato Plant. Studies using SIMS and Electro Probe X-Ray Microanalysis. Thesis Université Paris XII, France, 1999.

[2] Oliveira, A.H., Severo, M.I.G, Veado, M. A.R.V, Mangabeira, P.A. O. Galle, P Plasma Source Mass Spectrometry ( ICP-MS) Application to Multi-Element Analysis in Sediment and Water Samples Ann Arbor, Michigan, U.S.A 6-10 Agosto de 2000

[3] Severo, M.I.G, Oliveira, A.H, Mangabeira, P. A. O , Veado, M.R.V, Galle P and Souza, R.B., Concentration of Metal in Aquatics Crustacea in the Cachoeira Basin, BahiaBrazil

[4] Veado R.V. M.A., Oliveira, A H., Revel G. Pinnte G., Analysis and distribution of metals in the Paraopeba and the Das Velhas Rivers, Brazil , WaterSA. (2000), 26,2 : 249 . 254

[5] Levis, A.G., Bianchi,V, Tanmino,G and Pegoraro,B. Cytotoxic effects of hexavalent and trivalent chromium on mammalian cells in vitro. Br. J. Cancer 37:386-396, 1978.

Acknowlegement

This study was supported by a research grant from FAPESB and CNPq. We thanks Dr. Pierre Galle for SIMS analysis. 